\title{
p. Leu72Met MUTATION OF GHRELIN GHRL GENE IN CHILDREN WITH GASTROESOPHAGEAL REFLUX DISEASE
}

\author{
Marta Dats-Opoka \\ Department of propedeutics of pediatrics and medical genetics \\ Danylo Halytskyy Lviv National Medical University \\ 69 Pekarska str., Lviv, Ukraine, 79010 \\ martadats@gmail.com \\ Halyna Makukh \\ Senior research assistant \\ State Institution «Institute of Hereditary Pathology \\ Ukrainian National Academy of Medical Sciences» \\ 31 a Lysenko str., Lviv, Ukraine 79008 \\ makukh_halyna@ukr.net \\ Oleg Hnateyko \\ Department of propedeutics of pediatrics and medical genetics \\ Danylo Halytskyy Lviv National Medical University \\ 69 Pekarska str., Lviv, Ukraine, 79010 \\ State Institution «Institute of hereditary diseases National Academy of \\ Medical Sciences of Ukraine» \\ 31 a Lysenko str., Lviv, Ukraine 79008 \\ root@ihp.lviv.ua
}

\begin{abstract}
Gastroesophageal disease (GERD) is the one of most spread diseases that injures an esophagus. Taking into account the large number of factors that can cause GERD development already in child age, including genetic predisposition, it is necessary to analyze each of them in detail.

Aim of this work was to analyze a frequency and possible association type of p. Leu72Met mutation of GHRL gene in children with gastroesophageal reflux disease.

The analysis of clinical parameters and course of disease in the group of 100 schoolchildren with GERD was carried out. The molecular-genetic study of c.214C $>$ A locus of GHRL gene by CPR method (rs696217) was carried out in patients with GERD and 40 healthy children from the control group.

In $82 \%$ of children with GERD was revealed a GHRL 214CC (Leu/Leu) homozygous genotype, at $58 \%$ among children from the control group. GHRL 214CA (Leu/ Met) genotype was registered three times more seldom in children of the studied group comparing with ones from the control group: $15,0 \%$ and $42,5 \%$, respectively. It was established, that GHRL 214CC genotype presence conditions the increase of GERD development risk in 3,4 times. On the contrary, GHRL 214CA genotype manifests a reliable protective effect that is essentially decreased GERD development risk in a child at such genotype - 0,24 comparing with a conventional unit.

There was established alleles and genotypes distribution of c.214C $>$ A (p.Leu72Met) locus of GHRL gene in children with GERD. GHRL 214CC genotype is associated with threefold increase of GERD risk development. Gender differences as to GERD development risk at different genotypes of ghrelin gene were established. At GHRL 214CC (Leu/Leu) genotype the relative GERD risk for boys increased in more than 6 times. There were not established any differences in alleles and genotypes distribution depending on erosive or surface inflammatory changes of a gastrointestinal tract mucosa.
\end{abstract}

Keywords: gastroesophageal reflux disease, children, ghrelin, Leu72Met mutation.

\section{Introduction}

For today the one of cases of gastroesophageal reflux disease (GERD) is considered as a disorder of gastrointestinal tract upper parts motility with further emission of gastric acid in an 
esophagus. The inhibition of stomach emptying is a risk factor of GERD development and is observed nearly in 10-40\% of patients (Festi and others, 2009) [1, 2]. The regular irritation of an esophagus mucosa by gastric acid causes inflammatory changes and in some cases erosions or ulcers. The distinct correlation was established between the duration of stomach content effect on an esophagus and severity degree of its mucosa injury [3]. It is well-known, that stimulation of gastrointestinal tract motility and appetite are greatly influenced by ghrelin (GHRL) [4, 5]. Ghrelin, orexigenic motilin-like hormone, discovered in 1996 by M. Kojima and his colleges, who reported about it in 1999 [6]. The most amount of ghrelin (over $90 \%$ ) is in a stomach and duodenum. Lower amounts were reveled in a placenta [7], hypophysis, arched kernel of hypothalamus [8]. Ghrelin can increase a speed of stomach emptying and so, decrease an amount of gastric acid that reaches an esophagus. Ghrelin anti-inflammatory effects were also presented in the studies by Golestan and others, 2010; Nikoukar and others, 2014. Thus, ghrelin has a positive influence on an esophagus mucosa through anti-inflammatory mechanisms [2]. Ghrelin secretion increases under conditions of the negative energetic balance such as hunger, cachexy and anorexia, whereas its expression decreases under conditions of the positive energetic balance such as feeding, hyperglycemia and obesity [9]. Ghrelin is expressed by GHRL gene, several SNP are informed for it. In literature is actively studied the SNP allele polymorphism with obesity [10, 11], food behavior disorders [12] and metabolism disturbances [13], and also with gastric acid secretion [14] and fast stomach emptying $[15,16]$. Mutations in this gene can cause low levels of ghrelin, registered at obesity [17].

\section{Aim of research}

To analyze the frequency and possible association type of p. Leu72Met mutation of GHRL in children with gastroesophageal disease.

\section{Materials and methods}

The studied group consisted of 100 children 6-14 years old (in average 10,8 years), who underwent the stationary treatment at I-st pediatric department of the Municipal institution of Lviv regional council Lviv regional child clinical hospital (MI LRC LRCH “OHMADIT") with a diagnosed pathology of gastrointestinal tract. The control group included 40 of the same age without any gastrointestinal tract pathology. Among the children of studied group were 44 boys (44 $\pm 9,6 \%)$ and 56 girls (56 $\pm 9,6 \%$ ). All children underwent esophagogastroduodenoscopy using the videogastroscop "Fujinon" WG 88 FP, sonographic study of abdominal cavity organs, general clinical and laboratory studies, anamnestic data were analyzed. The group of 40 children without any manifestations of gastroesophageal reflux disease was formed as a control. The material of the study was 40 samples of DNA, separated from cells of bucal epithelium.

DNA of peripheral blood leucocytes was separated and purified by salting out method. PCR was carried out in automatic regime on the thermocycler “Tertsik” (,DNA-technology, Russia), oligonucleotide primers, mixture of dDNTP and thermostable DNA-polymerase Thermo Scientific $^{\mathrm{TM}}$ were used. The fragment of gene with the size $373 \mathrm{~b}$. p. was amplified using primers (GREL2F 5'- TGA CCT CAC TGT TTC TGG AAG-', GREL2R 5'-GGA CCC TGT TCA CTG CCA C-3'). The analysis of PCR products was carried out by PRFL (polymorphism of restrictive fragments lengths) method. Amplification products were visualized by electrophoresis in $2 \%$ agarose gel with ethidium bromide and scanned on the ultraviolet transiluminator "ECX-15. M (VILBER LOURMAT, France). The received signals were compared with lengths markers and sizes of received fragments were detected on this base. The results of agarose gel scanning were photographed by the digital camera "Gel Imager" (HELICON, Russia). The received data processing was carried out by conventional method of variational statistics with the calculation of odds ratio coefficient at $95 \%$ credible interval.

\section{Results}

The anamnesis and course of gastrointestinal tract diseases were analyzed in 300 schoolchildren. The criteria of inclusion in the studied group: complaints about gastrointestinal tract (pain in epigastral zone, nausea, heartburn, eructation, vomiting), apparent changes at the examination of 
gastrointestinal tract organs using additional methods, voluntary consent of parents for genetic examination. The criteria of exclusion: refusal of the examination at any stage. The results, received at the endoscopic examination were interpreted using Savari-Miller classification in G. N. J. Tytgat et. al. modification, 1990. For setting the diagnosis "functional dyspepsia", the Roman criteria IV were used. Among diseases of gastrointestinal tract in the studied group were revealed: erosive changes (erosive esophagitis, erosive gastritis, erosive duodenitis) - 16 children that is $16 \pm 7 \%$ (4 girls and 11 boys); surface inflammatory changes (distal esophagitis, surface gastritis, surface duodenitis) - 84 children that is $84 \pm 7 \%$ (48 girls and 32 boys). Gastroesophageal reflux disease with esophagitis was diagnosed most often among children of the studied group (59 $\pm 9 \%)$. On the second place by revelation frequency was a gastroesophageal reflux disease without esophagitis $(26 \pm 8 \%)$. Functional dyspepsia and a combination of duodenogastral and gastroesophagal reflux occurred in $10 \pm 6 \%$ and in $15 \pm 7 \%$, respectively. There was not revealed any reliable difference in the frequency of gastrointestinal tract diseases depending on sex.

All children of the studied group underwent the molecular-genetic examination of alleles of Leu$72 \mathrm{Met}$ locus of GHRL gene. As a result of PCR product processing by endonuclease of BsrI restriction, fragments with the following sizes were visualized on electrophoreogram: 373 b. p. - 214AA (Met/Met) genotype, 373 b. p. 272 b.p. and 101 b. p. - 214CA (Leu/Met) genotype, 272 b. p. and 101 b. p - 214CC (Leu/Leu) genotype, respectively. The electrophoreogram of molecular-genetic study of Leu72Met polymorphism of GHRL gene is presented on the Fig. 1.

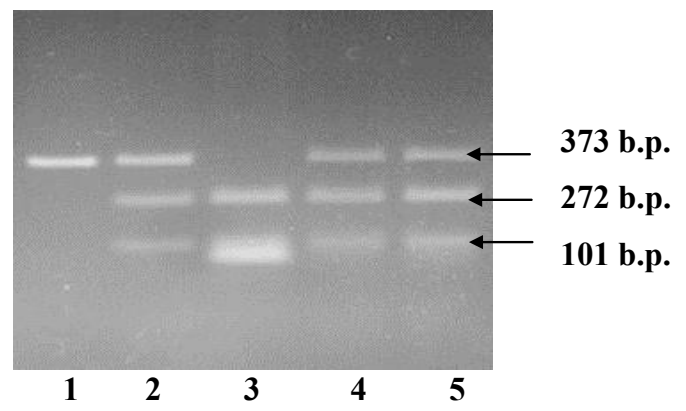

Fig. 1. Electrophoreogram of restrictive analysis of PCR products of SNP c.214C $>$ A, p. Leu72Met polymorphism of GHRL gene 1 (2\% agarose gel): 1-Met/Met genotype (373 b. p.); 2,4,5-Leu/Met genotype (373 b. p., 272 b. p., 101 b. p.); 3-Leu/Leu genotype (272 b. p., 101 b. p.)

As a result of DNA molecular-genetic analysis in 100 persons of the studied group with GERD and 40 persons from the control group there was established a genotype as to p.Leu72Met polymorphic locus of GHRL gene. One-nucleotide polymorphism is conditioned by cytosine (214C allele) replacement by adenine (214A allele) and, correspondingly, amino acid replacement of leucine by methionine - Leu72Met. In $82 \%$ of children with GERD was revealed GHRL 214CC (Leu/Leu) homozygous genotype, at $58 \%$ among children of the control group. GHRL 214CA (Leu/Met) genotype was registered three times more seldom in children of the studied group comparing with ones from the control group: $15,0 \%$ and $42,5 \%$, respectively. The results of genotypes distribution in children with GERD comparing with the control are presented on the Fig. 2.

As a result of the molecular-genetic analysis there were established statistically reliable differences in the ratio of GHRL gene genotypes between the group of children with GERD comparing with the control sample $\left(\chi^{2}=12,94, p=0,002\right)$. The calculated coefficients of GERD odds ratio dependence on c.214C $>$ A locus alleles of ghrelin gene are presented in the Table 1.

Taking into account the revealed differences as to p.Leu72Met polymorphic locus genotypes distribution of GHRL gene in children with GERD comparing with the control group, it was considered expedient to study allele frequency in the analyzed samples. Allele frequency indices of p. Leu72Met locus of GHRL gene in the studied groups of child patients are presented in the Table 2. 


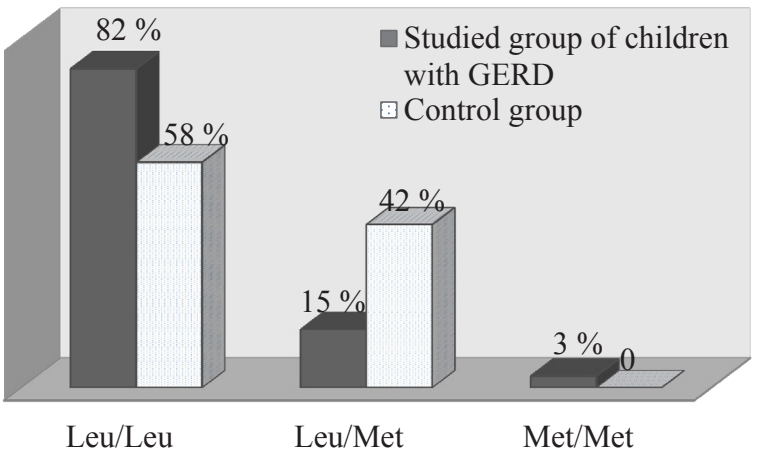

Fig. 2. Distribution of p.Leu72Met polymorphous locus genotypes of GHRL gene in children with GERD comparing with the control $\left(\chi^{2}=12,94, \mathrm{p}=0,002\right)$

Table 1

Distribution of $\mathrm{p}$. Leu72Met polymorphous locus genotypes of GHRL gene in studied groups

\begin{tabular}{|c|c|c|c|c|c|c|}
\hline \multirow{2}{*}{$G H R L$ genotype } & \multirow{2}{*}{$\begin{array}{c}\text { Studied group, } \% \\
n=100\end{array}$} & \multirow{2}{*}{$\begin{array}{c}\text { Control group, } \% \\
\qquad \mathbf{n}=\mathbf{4 0}\end{array}$} & \multirow{2}{*}{$\chi^{2}$} & \multirow{2}{*}{$\mathbf{p}$} & \multicolumn{2}{|c|}{ OR } \\
\hline & & & & & value & $95 \%$ CI \\
\hline GHRL 214CC & 82,0 & 57,5 & & & 3,37 & $1,50-7,56$ \\
\hline GHRL 214CA & 15,0 & 42,5 & 12,94 & $0,002 *$ & 0,24 & $0,10-0,55$ \\
\hline GHRL 214AA & 3,0 & 0,0 & & & 2,91 & $0,15-57,58$ \\
\hline
\end{tabular}

Note: $n$ - number of persons, $p$ - significance of differences in genotypes distribution between control and studied groups, *-statistically reliable value, OR - odds ratio coefficient

Table 2

Allele frequency of $\mathrm{p}$. Leu72Met polymorphous locus of GHRL gene in the studied groups

\begin{tabular}{|c|c|c|c|c|c|c|}
\hline \multirow[b]{2}{*}{$\begin{array}{c}\text { Alleles of } \\
G H R L \text { gene }\end{array}$} & \multicolumn{2}{|c|}{ Frequency, \% } & \multirow[b]{2}{*}{$\chi^{2}$} & \multirow[b]{2}{*}{$\mathbf{p}$} & \multirow{2}{*}{\multicolumn{2}{|c|}{ OR }} \\
\hline & $\begin{array}{c}\text { Studied group, } \% \\
\quad \mathrm{n}=100\end{array}$ & $\begin{array}{c}\text { Control group, } \% \\
n=40\end{array}$ & & & & $95 \%$ CI \\
\hline GHRL 214C & 89,5 & 78,8 & & م 02 \% & 2,30 & $1,14-4,64$ \\
\hline GHRL 214A & 10,5 & 21,3 & & & 0,43 & $0,22-0,88$ \\
\hline
\end{tabular}

Note: $n$ - number of persons, $p$ - significance of differences between control and studied groups, * - statistically reliable value, OR - odds ratio coefficient

As it is testified by the results, presented in the table 2 , statistically reliable differences were established in the frequencies of normal $\mathrm{C}$ and low-functional A alleles of c.214C $>$ A (p. Leu72Met) locus of GHRL gene in the studied groups of patients $\left(\chi^{2}=5,63, \mathrm{p}<0,05\right)$. The calculation of the odds ratio coefficient revealed a reliable effect as to A allele: $\mathrm{OR}=0,43, \mathrm{CI}: 0,22-0,88$ and association of $\mathrm{C}$ allele with the reliable increase of GERD risk in 2,3 times at the credible interval 1,14-4,64.

Gender differences as to alleles and genotypes distribution of c.Leu72Met locus of GHRL gene were analyzed (Table 3 ).

Thus, in $83,9 \%$ of girls and 79,5 \% of boys with GERD was revealed GHRL 214CC - Leu/Leu homozygous genotype that was similar to girls of the control group. The essential difference at gender analysis was observed among boys: the frequency of GHRL Leu/Met heterozygous genotype among boys of the studied group was $16 \%$ and $60 \%$ in the control $(\mathrm{p}=0,01)$.

On the Fig. 3 is presented the distribution in established genotype groups depending on injures severity (erosive changes and surface inflammatory changes) of a gastrointestinal tract. 
Table 3

Genotypes distribution of c. Leu72Met polymorphous locus of GHRL gene depending on sex of patients of the studied groups

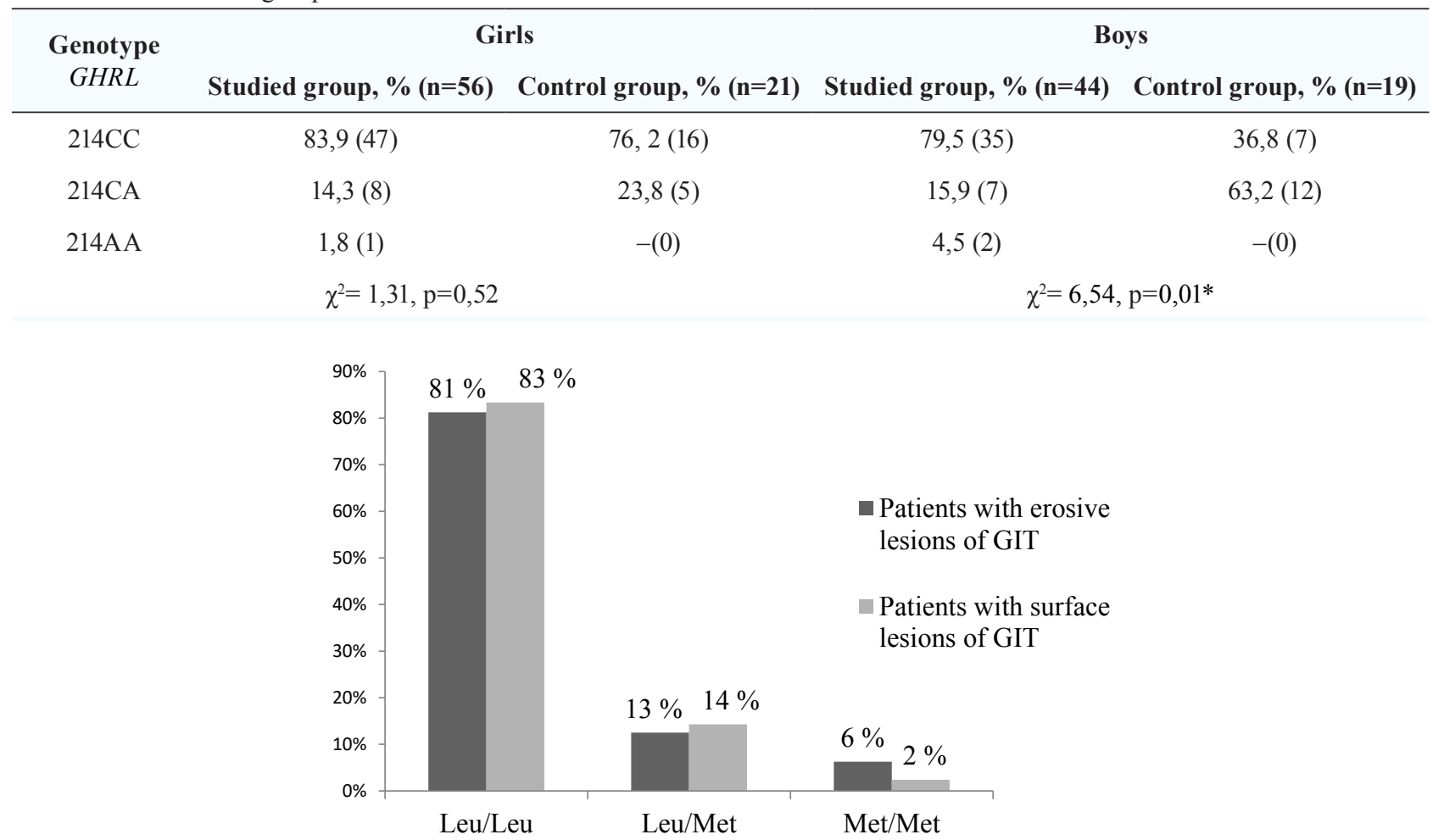

Fig. 3. Distribution of p. Leu72Met polymorphous locus genotypes $G H R L$ gene in children with GERD with erosive and surface inflammatory changes

There were not revealed any reliable differences as to the frequencies of certain genotypes of c.214C $>$ A (p. Leu72Met) locus of GHRL gene in the studied groups of patients, distributed depending on gastrointestinal tract lesion severity.

\section{Discussion}

GERD occur in 8,7-17 \% of children with gastroenterological diseases [18]. The world experience of treatment testifies that GERD early diagnostics decreases a risk of complications development. [2, 19] Extra-esophageal GERD manifestations [20-22], and revelation of typical esophageal symptoms only at 14-15 years old [23] conditions the necessity of searching new diagnostic possibilities. The presence of a genetic component in GERD development is proved by twin studies and provides multifactor etiology. [24] Thus, the hypothesis about predisposition genes of GERD development is reliable. Identification of such genes and alleles is topical for both early diagnostics and prophylaxis of GERD and for the further explanation of their development mechanisms through the comprehensive study of pathophysiological processes of these genes expression products. The connection between ghrelin and allele polymorphisms of its genes with digestive system diseases is specially discussed $[2,5]$.

In the work are presented the results of the distribution of alleles and genotypes of c. $214 \mathrm{C}>\mathrm{A}$ (p. Leu72Met) locus of GHRL gene in the group of schoolchildren with GERD comparing with the control group of children without a gastrointestinal tract pathology. As it is testified by the results of received data statistical processing and determined coefficient of odds ratio that represents a risk of GERD development, the differences in genotypes frequencies of the studied and control groups are significant like OR coefficients for GHRL 214CC and GHRL 214CA genotype (Table 3). It was established, that GHRL 214CC genotype conditions the increase of GERD risk in 3,4 times at the credible interval CI: 1,50-7,56. On the contrary, GHRL 214CA genotype demonstrates the credible 
protective effect: $\mathrm{OR}=0,24$, CI: $0,10-0,55$. So, in a child with such genotype GERD development risk is essentially decreased - 0,24 comparing with a conventional unit. The high reliability degree of genotypes distribution differences was received at a premise of recessive type of $214 \mathrm{C}$ allele of GHRL manifestation ( $\mathrm{p}=0,003)$. The received data testify that $214 \mathrm{C}$ allele in homozygous state (Leu/Leu genotype) conditions the increase of GERD development risk in 3,4 times. There was shown the expressed protective effect as to GHRL 214A (72Met) allele of GHRL gene: the odds ratio coefficient is 0,43 at CI: $0,22-0,88$ (Table 2).

It must be noted that ghrelin gene GERD risk allele is more spread in general population. The frequency of minor allele of GHRL 214A (Met72) in the control group was $21 \%$, and $11 \%$ in the studied one. These results concern to Ukrainian population. It must be noted, that the study of such genetic locus among Ukrainians was not carried out, and we first inform about the frequencies of alleles of p.Leu72Met locus of GHRL gene. In different ethnic samples its frequency is 7,4-22,35\%. It was revealed, that the frequencies of Met72 allele in Europeans are 7,4-12,9\% (Vivenza and others, 2004; Bing and others, 2005; Magera and others, 2006; Zavarella and others, 2008) [25-28]; 18,1 \% in Koreans ( Kim and others, 2006) [29] and 20\% in Japanese (Ando and co-author, 2006; Kuzuya and others, 2006) [30,31]. The frequency of Met72 allele in our sample is $21 \%$, a bit higher than the data, given by HapMap $(15,6 \%, \mathrm{~N}=90)$.

As it is testified by the data, presented in the Table 3, in this work were revealed certain features in p.Leu72Met locus genotypes distribution of GHRL in persons of the different sexes. Namely: absence of differences in girls group at essential differences among boys. Such results testify that the data about GERD risk at Leu/Leu genotype, received in the general studied group, are proved for boys with more reliability degree. Thus, the relative risk of GERD for boys at GHRL 214CC (Leu/Leu) genotype is increased in more than 6 times (OR=6,7, CI: 2,04-21,82). GHRL 214CA (Leu/Met) heterozygous genotype is protective as to $\mathrm{GERD}(\mathrm{OR}=0,11, \mathrm{CI}$ : $0,03-0,38)$ in boys and in general group.

\section{Conclusions}

1. The distribution of alleles and genotypes of c. $214 \mathrm{C}>\mathrm{A}$ (p. Leu72Met) locus of GHRL gene in children with GERD was established.

2. The genetic factor that increases GERD risk is $214 \mathrm{C}$ allele of GHRL gene (Leu) in genotype. GHRL 214CC genotype is associated with a threefold increase of GERD development risk.

3. Gender differences as to GERD development risk at different genotypes of ghrelin gene were established. At GHRL 214CC (Leu/Leu) genotype the relative GERD risk for boys is increased in more than 6 times. GHRL 214CA (Leu/Met) heterozygous genotype is protective as to GERD boys and in general group.

4. Any differences in alleles and genotypes distribution depending on erosive or surface inflammatory changes of a gasrtointestinal tract mucosa were not established.

\section{References}

[1] Moayyedi, P., Talley, N. J. (2006). Gastro-oesophageal reflux disease. The Lancet, 367 (9528), 2086-2100. doi: 10.1016/s0140-6736(06)68932-0

[2] Seyed, M. M., Fatemeh, N., Mahdieh, F., Gholamreza, H., Hamideh, A., Hamid, S. (2015). Effects of exogenous ghrelin on experimental reflux esophagitis model in male rat. Journal of Physiology and Pathophysiology, 6 (2), 6-12. doi: 10.5897/jpap2015.0098

[3] Suzuki, H., Iijima, K., Scobie, G., Fyfe, V., McColl, K. E. L. (2005). Nitrate and nitrosative chemistry within Barrett’s oesophagus during acid reflux. Gut, 54 (11), 1527-1535. doi: 10.1136/gut.2005.066043

[4] Asakawa, A., Inui, A., Kaga, O., Yuzuriha, H., Nagata, T., Ueno, N. et. al. (2001). Ghrelin is an appetite-stimulatory signal from stomach with structural resemblance to motilin. Gastroenterology, 120 (2), 337-345. doi: 10.1053/gast.2001.22158

[5] Nahata, M., Saegusa, Y., Harada, Y., Tsuchiya, N., Hattori, T., Takeda, H. (2013). Changes in Ghrelin-Related Factors in Gastroesophageal Reflux Disease in Rats. Gastroenterology Research and Practice, 2013, 1-8. doi: 10.1155/2013/504816 
[6] Kojima, M., Hosoda, H., Date, Y., Nakazato, M., Matsuo, H., Kangawa, K. (1999). Ghrelin is a growth-hormone-releasing acylated peptide from stomach. Nature, 402 (6762), 656-660. doi: 10.1038/45230

[7] Ariyasu, H., Takaya, K., Tagami, T., Ogawa, Y., Hosoda, K., Akamizu, T. et. al. (2001). Stomach Is a Major Source of Circulating Ghrelin, and Feeding State Determines Plasma Ghrelin-Like Immunoreactivity Levels in Humans. Journal of Clinical Endocrinology \& Metabolism, 86 (10), 4753-4758. doi: 10.1210/ jc. 86.10 .4753

[8] Date, Y., Kojima, M., Hosoda, H., Sawaguchi, A., Mondal, M. S., Suganuma, T. et. al. (2000). Ghrelin, a Novel Growth Hormone-Releasing Acylated Peptide, Is Synthesized in a Distinct Endocrine Cell Type in the Gastrointestinal Tracts of Rats and Humans. Endocrinology, 141 (11), 4255-4261. doi: 10.1210/ en.141.11.4255

[9] Hosoda, H., Kojima, M., Kangawa, K. (2006). Biological, Physiological, and Pharmacological Aspects of Ghrelin. Journal of Pharmacological Sciences, 100 (5), 398-410. doi: 10.1254/jphs.crj06002x

[10] Vitolo, E., Santini, E., Seghieri, M., Giannini, L., Coppede, F., Rossi, C. et. al. (2016). Heterozygosity for the rs696217 SNP in the Preproghrelin Gene Predicts Weight Loss After Bariatric Surgery in Severely Obese Individuals. Obesity Surgery, 27 (4), 961-967. doi: 10.1007/s11695-016-2387-6

[11] Gueorguiev, M., Lecoeur, C., Meyre, D., Benzinou, M., Mein, C. A., Hinney, A. et. al. (2009). Association Studies onGhrelinandGhrelin ReceptorGene Polymorphisms With Obesity. Obesity, 17 (4), 745-754. doi: 10.1038/oby.2008.589

[12] Monteleone, P., Tortorella, A., Castaldo, E., Di Filippo, C., Maj, M. (2007). The Leu72Met polymorphism of the ghrelin gene is significantly associated with binge eating disorder. Psychiatric Genetics, 17 (1), 13-16. doi: 10.1097/ypg.0b013e328010e2c3

[13] Ukkola, O. (2011). Genetic variants of ghrelin in metabolic disorders. Peptides, 32 (11), 2319-2322. doi: 10.1016/j.peptides.2011.04.013

[14] Date, Y., Nakazato, M., Murakami, N., Kojima, M., Kangawa, K., Matsukura, S. (2001). Ghrelin Acts in the Central Nervous System to Stimulate Gastric Acid Secretion. Biochemical and Biophysical Research Communications, 280 (3), 904-907. doi: 10.1006/bbrc.2000.4212

[15] Nahata, M., Muto, S., Oridate, N., Ohnishi, S., Nakagawa, K., Sadakane, C. et. al. (2012). Impaired ghrelin signaling is associated with gastrointestinal dysmotility in rats with gastroesophageal reflux disease. AJP: Gastrointestinal and Liver Physiology, 303 (1), G42-G53. doi: 10.1152/ajpgi.00462.2011

[16] Yanai, M., Mochiki, E., Ogawa, A., Morita, H., Toyomasu, Y., Ogata, K. et. al. (2012). Intragastric administration of rikkunshito stimulates upper gastrointestinal motility and gastric emptying in conscious dogs. Journal of Gastroenterology, 48 (5), 611-619. doi: 10.1007/s00535-012-0687-8

[17] Krzyzanowska-Swiniarska, B., Kempa, A., Robaczyk, M. (2005). Preproghrelin gene, ghrelin receptor and metabolic syndrome. Przegl Lek, 62 (4), 230-233.

[18] Unifikovani klinichni protokoly nadannya dopomogy dityam iz zaxvoryuvannyamy organiv travlennya (2013). MOZ Ukrayiny, No. 59. Available at: http://www.moz.gov.ua/ua/portal/dn_20130129_0059.html

[19] Pediatric Gastroesophageal Reflux Clinical Practice Guidelines (2009). Journal of Pediatric Gastroenterology and Nutrition, 49, 498- 547.

[20] Maev, I. V., Yurenev, G. L., Burkov, S. G. et. al. (2007). Vnepishchevodnye proyavleniya gastroehzofageal'noj reflyuksnoy bolezni. Terapevticheskyi arhiv, 3, 57-66.

[21] Shherbynina, M. B., Budzak, I. Ya. (Eds.) (2008). Kardialni proyavy gastroezofagelnoyi reflyuksnoyi khvoroby: taktyka vedennya paciyentiv. Kyiv, 23.

[22] Maev, I. V., Barer, G. M., Busarova, G. A., Pustovoit, E. V., Polikanova, E. N., Burkov, S. G., Yurenev, G. L. (2005). Stomatologicheskie proyavleniya gastroehzofageal'noj reflyuksnoj bolezni. Klinicheskaya medicina, 11, 33-38.

[23] Kryuchko, T. O., Nesina, I. M. (2013). Osoblyvosti pozastravokhidnykh proyaviv hastroezofaheal'noyi reflyuksnoyi khvoroby u ditey. Zdorov`ya dytyny, 4 (47), 16-19. 
[24] Post, J. C., Ze, F., Ehrlich, G. D. (2005). Genetics of pediatric gastroesophageal reflux. Current Opinion in Allergy and Clinical Immunology, 5 (1), 5-9. doi: 10.1097/00130832-200502000-00003

[25] Vivenza, D., Rapa, A., Castellino, N., Bellone, S., Petri, A., Vacca, G. et. al. (2004). Ghrelin gene polymorphisms and ghrelin, insulin, IGF-I, leptin and anthropometric data in children and adolescents. European Journal of Endocrinology, 151 (1), 127-133. doi: 10.1530/eje.0.1510127

[26] Bing, C., Ambye, L., Fenger, M., Jorgensen, T., Borch-Johnsen, K., Madsbad, S., Urhammer, S. A. (2005). Large-scale studies of the Leu72Met polymorphism of the ghrelin gene in relation to the metabolic syndrome and associated quantitative traits. Diabetic Medicine, 22 (9), 1157-1160. doi: 10.1111/j.14645491.2005.01575.x

[27] Mager, U., Kolehmainen, M., Lindstrom, J., Eriksson, J., Valle, T., Hamalainen, H. et. al. (2006). Association Between Ghrelin Gene Variations and Blood Pressure in Subjects With Impaired Glucose Tolerance. American Journal of Hypertension, 19 (9), 920-926. doi: 10.1016/j.amjhyper.2006.02.017

[28] Zavarella, S., Petrone, A., Zampetti, S., Gueorguiev, M., Spoletini, M., Mein, C. A. et. al. (2007). A new variation in the promoter region, the $-604 \mathrm{C}>\mathrm{T}$, and the Leu72Met polymorphism of the ghrelin gene are associated with protection to insulin resistance. International Journal of Obesity, 32 (4), 663-668. doi: 10.1038/sj.ijo.0803766

[29] Kim, S.-Y., Jo, D.-S., Hwang, P. H., Park, J. H., Park, S. K., Yi, H. K., Lee, D.-Y. (2006). Preproghrelin Leu72Met polymorphism is not associated with type 2 diabetes mellitus. Metabolism, 55 (3), 366-370. doi: 10.1016/j.metabol.2005.09.011

[30] Ando, T., Komaki, G., Naruo, T., Okabe, K., Takii, M., Kawai, K. et. al. (2006). Possible role of preproghrelin gene polymorphisms in susceptibility to bulimia nervosa. American Journal of Medical Genetics Part B: Neuropsychiatric Genetics, 141B (8), 929-934. doi: 10.1002/ajmg.b.30387

[31] Kuzuya, M., Ando, F., Iguchi, A., Shimokata, H. (2006). Preproghrelin Leu72Met variant contributes to overweight in middle-aged men of a Japanese large cohort. International Journal of Obesity, 30 (11), 1609-1614. doi: 10.1038/sj.ijo.0803296 